International Research Journal of Engineering, IT \& Scientific Research (IRJEIS) Journal Homepage: http://ijcu.us/online/journal/index.php/irjeis

Vol. 2 Issue 7, July 2016, pp. 50 53

ISSN: 2454-2261 Impact Factor: 3.605

DOI: 10.6084/m9.figshare.3437300 | ORCID: 0000-0002-3163-0991 | Thomson Reuters ID: C-6767-2016 |

\title{
Transformation of Eliza from a Flower Girl to Duchess
}

Kajal Kapoor *

\section{Article history:}

Received April 7 th $^{\text {, }} 2016$

Revised May 10 $0^{\text {th }}, 2016$

Approved June $16^{\text {th }}, 2016$

\section{Keywords:}

Eliza;

Pygmalion;

Transformation;

Flower-Girl;

Dignified Lady;

\begin{abstract}
George Bernard Shaw's Pygmalion is a complex work of art and such a number of themes and ideas stand out. However, in the play its central theme is the education of Eliza Doolittle and the progress of her soul from spiritual darkness to light. Paper discusses how Eliza a poverty-stricken, shabby girl becomes heroine of the play, which is concerned entirely with her transformation from a flower girl to a lady.Eliza proves difference with a flower girl is not how she behaves but how she is treated. She achieves spiritual illumination through successive stages of despair, self-realization, and the ultimate achievement of social identity and a sense of belonging. Therefore, her transformation is both internal and external.In the words of Jane Rolland Martin-"Eliza's is nothing less than a whole person transformation."
\end{abstract}

Copyright () 2016 International Journal of College and University. All rights reserved.

Article cited by | DOI |Orcid | OAI DOAJ | Thomson Reuters | Scopus |

\section{Author correspondence:}

First Author,

BA (Hons) English, Amity University

Email Id : kapoorrm1711@gmail.com

\section{Introduction}

George Bernard Shaw's Pygmalion is a complex work of art and such a number of themes and ideas stand out. However, in the play its central theme is the education of Eliza Doolittle and the progress of her soul from spiritual darkness to light. Transformation of Eliza from a Flower Girl to Duchess. The transformation of Eliza is not only considered to language development but also in her perception of the world and her own views on life. A variety of influences contribute to Eliza transformation. Professor Henry Higgins systematic way of teaching Eliza phonetics and grammar enables Eliza to pronounce words correctly and she speaks grammatically. But there are also other characters in the play who contribute to her learning. She receives an informal education in various aspects of upper-class living which include maintaining cleanliness and hygiene (through the housekeeper Mrs. Pearce manners and gentility through Colonel Pickering and Mrs. Higgins)

\section{Research Method}

Research means to investigate more about particular content. For this paper I have referred several books and also made notes so that I can focus on my paper and I had tried my best to cover all the details required for the paper. As the paper entirely discusses about transformation of a single character Eliza from a Flower Girl to Duchess I had tried to focus mainly on her development as a person and also tried to do full justice byproviding all the relevant details.

\section{Results and Analysis}

When the play opens, we find that Eliza is an ignorant girl, selling flowers in Covent Garden and speaking the kind of cockney, which only the native Londoners can understand. She has an almost unintelligible manner of speaking English. She speaks cockney, i.e. a London Dialect so difficult to

${ }^{*}$ BA (Hons) English, Amity University 
understand that often it seems that she is merely making incoherent noises. She pronounces words in such a way, and speaks with such an accent, that even Professor Henry Higgins is bewildered. She expresses her grievance or her sense of injustice by 'boohooing' and by uttering certain sounds which betray her complete lack of education and her belonging to the lowest stratum of society. When a bystander tells her that the notetaker might be a police detective who would bring against her a charge that she has been manipulating customers for herself and she feels alarmed, "I aren't done nothing wrong by speaking to the gentleman. I've a right to sell flowers if I keep of the kerb."And she is definitely a bold girl who cannot be put down easily. When Professor Henry Higgins asks her to stop "Boohooing" or seek shelter anywhere else other than church she replies: "I've a right to be here if I like same as you."Afterwards this poverty-stricken, shabby and unromantic girl is to become heroine of the play, which is concerned entirely with her transformation from a flower girl to a lady.

Although she is not a timid girl even at this stage when she is poor and is leading a wretched and poor life. Her going home in a taxi when she hardly can afford this luxury. This also reflects spirit of defiance in her and also her pride and ambition, when the taxi-driver where she would like to be taken, her reply is: "Buckingham Palace" where the king lives and when taxi-driver asks about what business she have at Buckingham Palace she replied “Of course I haven't. But I wasn't going to let him know that."Because she tends to make it appear that she belongs to a higher status than the one she actually belongs and this makes her hire the taxi to go home. When subsequently, the taxi-driver asks if she has ever been in a taxi before, she replies with dignity: "Hundreds and thousands of times, young man." although it is evident that she has never been in a taxi before. This shows mentality and fondness for showing off as a flower girl. Her education begins when the very next day she comes at the residence of Professor Henry Higgins to take lessons in phonetics. As Higgins accepts the bet of Colonel Pickering that he would transform the shabby flower girl into a lady who would be able to present herself as a Duchess in the garden party of an ambassador. "What is life but a series of inspired follies? The difficulty is to find them to do. Never lose a chance; it not comes every day. I shall make duchess of this draggle tailed guttersnipe."The first turning point of Eliza transformation was when Henry Higgins instructs Mrs. Pearce to take Eliza into the bathroom, strip her naked, and scrub her body clean with a brush and soap, Eliza feels shocked because she has never before taken off all her clothes as she has never taken a full bath in all her life. When she is actually taken into the bathroom, she begins to screams loudly. She is shocked at seeing her own nakedness in the mirror on the bathroom wall. She experiences sense of shame on seeing the reflection of her own naked body in the mirror. This was for the first ever time when Eliza was transforming externally from a shabby flower girl to a clean dignified lady. Her transformation was not easy but she has that courage, determination and thus she faces all the situations very bravely. Therefore, the education of Eliza in phonetics, her new environment and her training in middle class manners and morality transform her. As her education proceeds she realizes that the difference with a flower girl is not how she behaves but how she is treated. Eliza becomes duchess in the eyes of others except Henry Higgins as he still considers her the same "a guttersnipe"even when her performance had been improved... Her speech and personal impression had drastically changed then too he continues to treat her as low-class flower girl."Well, when I've done with her, we can throw her back into the gutter; and then it will be her own business again, so that's all right."On the other hand, Colonel Pickering always considers and regarded Eliza as a lady because from the beginning he had adopted positive approach andattitude towards her.

Eliza of Act III is quite different from the Flower girl of Act I. She finds the lessons to be an ordeal. As she had a receptive ear after a few months of training, she is put to the test at the 'at home' at Mrs. Higgins (Henry Higgins mother) flat. She is beautiful, but a diamond in the rough. Her manners at first were well controlled, but as soon she relaxes she reverts to old characteristics. At this small social gathering, she speaks English very well and creates quite a sensation. But In reply to a simple question whether it would rain that day, she gives the correct reply but the reply is worded so abruptly that it produces a ridiculous effect. She says, "The shallow depression in the west of these islands is likely to move slowly in an easterly direction. There are no indications of any great change in the barometrical situation."As she had progressed much in her education and now shedresses more like a lady, behaves like a lady and above all is consider as a"duchess"and therefore impressed all. But her"small talk"about her Aunt "Why should she die of influenza? She comes through diphtheria right enough the year before. I saw her with my eyes. Fairly blue with it, she was. They all thought she was dead; but my father he kept ladling gin down her throat till she came to so sudden that she bit the bowl off the spoon."She even makes use of the forbidden word "bloody" in her talk. Thus it betrays her social background and therefore to cover up situation Higgins says, "Oh, that's the new small talk. To do a person it means to kill them."She is still weak in what a lady should talk at a social gathering. When there is a reference made to the possible outbreak of influenza, Eliza says that her aunt had been murdered by some of her own relatives who had killed her only to take possession of the old woman's new straw hat. "What become of her new straw hat that should have come to me? Somebody pinched it; and 
what I say is, them as pinched it done her in." And then Eliza goes on to speak of the habitual drunkenness of her father. "It never did him no harm what I could see. But then he did not keep it up regular. [Cheerfully] On the burst, as you might say, from time to time. And he was always more agreeable when he had a drop in. When he was out of work, my mother used to give him four pence and tell him to go out and not come back until he'd drunk himself cheerful and loving-like. There are lots of women that have to make their husbands drunk to make them fit to live with. [Now quite at her ease] You see, it's like this. If a man has a bit of a conscience, it always takes him when he's sober; and then it makes him low-spirited. "A drop of booze just takes that off and makes him happy." In short, Eliza talks about matters which easily betray her low origin, even though the language which she speaks is worthy of a highly educated person. From her way of talking, it becomes clear that, while she has command over the language and can speak it well, she has not yet learnt what subjects should be talked about at a gathering of middle-class or upper middle class people. His mother tells Higgins that Eliza is a triumph of his art and also of the art of her dressmaker and for a moment that she does not give herself away in every sentence she says, you must be perfectly cracked about her.But throughout her visit Shaw makes it clear that with more training she will become a lovely young woman, precisely correct in every manner and eventually a person to be considered and since three months are still there to complete the process of her education. Higgins continues to give her lessons in phonetics. Eliza is a talented pupil and soon she is able to talk fluently and correctly like any "high born lady".At the conclusion of six months of training, she is again subjected to a test. This time she develops as a highly accomplished and cultured lady and also proves to be successful in her transformation and not only considers merely as a duchess but also as a princess with royal blood in her veins and also refers as "Hungarian"(One of Royal Blood) at Ambassador's Garden Party. All were deceived by her lady-like manners and it is said that she speaks like "Queen Victoria" herself. As her talk completely suits traits of lady of the highest rank. Besides this, she she looks so attractive, graceful and well-dressed. All the guests at the reception stop talking in order to look at her, to admire her dress, her jewels and her majestic figure. Even the hostess says: "Oh, of course, I agree she must be a princess at least." It has all been a grand success. She has acquired aspirations and ambitions and seeks for emotional fulfillment and Colonel Pickering remarks her that "You have won it ten times over."

In this connection A.C. Ward writes, "Speech, Shaw believed, was the great barrier between social classes, and Higgins' experiment with Eliza was intended to support the proposition that the difference between a flower-girl and a duchess is no greater than the difference between the sounds they make when talking. The immediate stage in Eliza's progress gives rise to the admirable Act III of the play, which shows her in command of pedantic correctness of pronunciation and great beauty of tone, which she can only use, however, either with the slow deliberation of an automaton or with ease in her linguistic expression. Now there is no difference between the duchess and Eliza."

\section{Conclusion}

However, during the course of her education in phonetics, her soul has been awakened and she has progressed from spiritual darkness to light. She achieves spiritual illumination through successive stages of despair, self-realization, illumination and the ultimate achievement of social identity and a sense of belonging. The hidden possibilities of her soul have been fully developed. She is transformed spiritually and that is the real education. She now seeks social identity. Her soul has been lifted out of her social environment and she cannot return to it. But also she does not belong to the middle class to which her education has raised her. Eliza, the modern Cinderella has suffered terribly at the hand of her step mother, her father, Professor Henry Higgins and even Mrs. Pearce the housekeeper. But her soul has not been crushed. She does not lose her vitality and her spirit. Thus she develops into an independent woman. Therefore, her transformation is both internal and external. In the words of Jane Rolland Martin- "Eliza's is nothing less than a whole person transformation."

\section{Acknowledgement}

Paper talks about transformation of a single character Eliza from a Flower Girl to a Duchess. Paper aims to show her transformation both internally and externally. I Kajal Kapoor would like to express my special gratitude to my mentor Dr. Geetanjali Joshi Mishra for her guidance and support and also for her valuable ideas and suggestions which she provided in making my paper Transformation of Eliza from a Flower Girl to Duchess. Through this paper I acknowledged several new facts and will continue my research work so that it can enhance my knowledge. 


\section{References}

[1] Shaw Pygmalion orient blackswan private limited 1954 b.b.press, noida.

[2] Shaw Pygmalion coles notes Rama brothers India pvt. ltd. 1998 chaman enterprises New Delhi.

[3] Shaw Pygmalion Rama brothers India private limited 1991 chaman enterprises New Delhi.

\section{Biography of Authors}

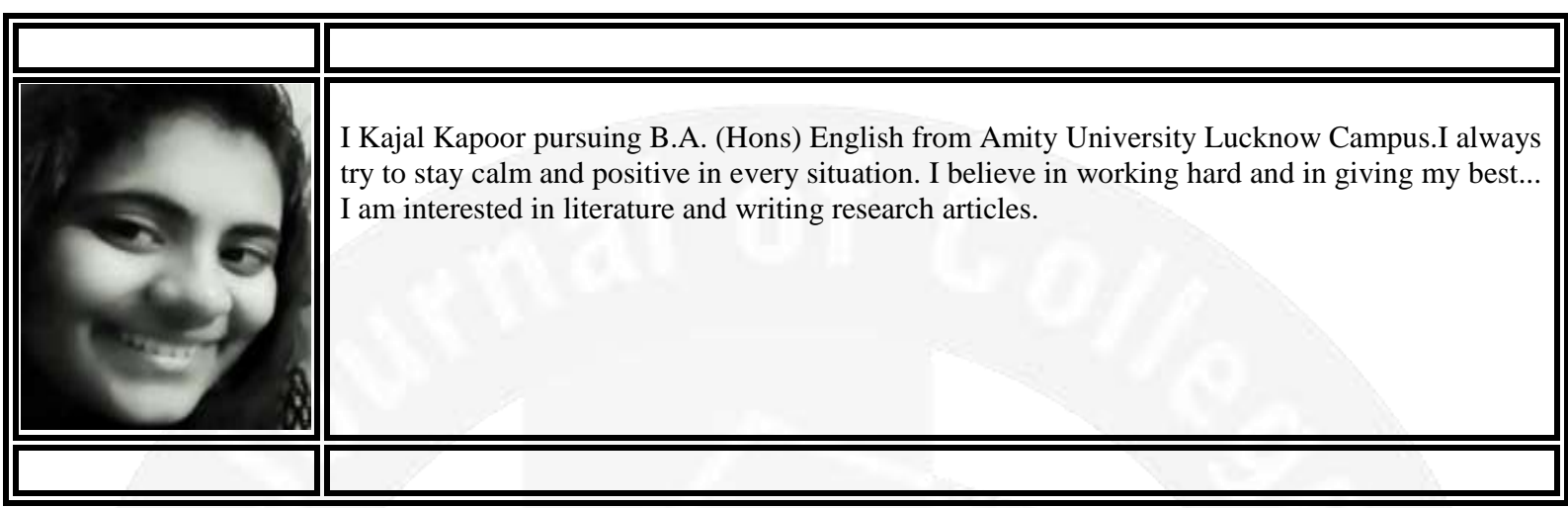

